\title{
Pelatihan Penyusunan Bahan Ajar Berbasis Multimedia Bagi Guru-Guru Yayasan Ali Imron Pakamban Sumenep
}

\author{
Mohammad Nafie Jauhari, Juhari, Mohammad Jamhuri \\ Jurusan Matematika, UIN Maulana Malik Ibrahim Malang \\ nafie.jauhari@uin-malang.ac.id
}

\section{Info Artikel \\ Riwayat Artikel: \\ Diterima: Mei 2020 \\ Direvisi: Agustus 2020 \\ Diterbitkan: September 2020}

\begin{tabular}{l}
\hline Keywords: \\
Learning Media \\
Ali Imron \\
Multimedia
\end{tabular}

\begin{abstract}
Learning media is a useful tool and intermediary for facilitating the teaching and learning process to streamline communication between teachers and students. This community service activity is divided into three main activities, namely the delivery of concepts or theories of multimedia, types of multimedia, the use of multimedia, and making presentations using practical and interactive PowerPoints tools; second, training on how to use PowerPoint effectively; and third, evaluation on the ability of training participants in making multimedia-based teaching materials.
\end{abstract}

\section{Korespondensi:}

Mohammad Nafie Jauhari,

UIN Maulana Malik Ibrahim Malang,

Jl. Gajayana No. 50 Malang, Jawa Timur, Indonesia 65144

nafie.jauhari@uin-malang.ac.id

\section{PENDAhuluan}

Peningkatan mutu pendidikan merupakan salah satu unsur konkrit yang sangat penting dalam upaya peningkatan kualitas sumber daya manusia. Sejalan dengan itu, hal yang sangat penting untuk diperhatikan adalah masalah prestasi belajar. Masalah umum yang sering dihadapi oleh peserta didik khususnya siswa adalah masih belum banyaknya prestasi belajar yang memuaskan. Terdapat banyak faktor yang menyebabkan prestasi belajar tersebut tidak maksimal, baik faktor-faktor yang berada dalam diri siswa seperti tingkat kecerdasan yang rendah, kurangnya motivasi belajar, cara belajar yang kurang efektif, minimnya frekuensi dan jumlah waktu belajar, tingkat disiplin diri yang rendah, maupun faktor-faktor yang berada di luar diri siswa seperti media belajar atau bahan ajar efektif yang masih kurang disediakan pihak sekolah. Untuk mencapai prestasi belajar yang memuaskan, maka penting untuk mengembangkan sistem pengajaran yang didukung dengan teknologi. Teknologi multimedia telah menjanjikan potensi besar dalam merubah cara seseorang untuk belajar, untuk memperoleh informasi, menyesuaikan informasi, dan menyampaikan informasi.

Peningkatan mutu pendidikan merupakan salah satu unsur konkrit yang sangat penting dalam upaya peningkatan kualitas sumber daya manusia[1]. Sejalan dengan itu, hal yang sangat penting untuk diperhatikan adalah masalah prestasi belajar. Masalah umum yang sering dihadapi oleh peserta didik khususnya siswa masih cukup banyak yang belum dapat mencapai prestasi belajar yang memuaskan. Sebenarnya banyak faktor yang menyebabkan prestasi belajar tersebut mengalami kegagalan dalam bidang akademik baik faktor-faktor yang berada dalam diri siswa maupun faktor-faktor yang berada di luar diri siswa seperti tingkat kecerdasan yang rendah, kurangnya motivasi belajar, cara belajar yang kurang efektif, minimnya frekuensi dan jumlah waktu belajar, tingkat disiplin diri yang rendah, media belajar atau bahan 
ajar yang masih kurang disediakan pihak sekolah dan sebagainya[2]. Teknologi multimedia telah menjanjikan potensi besar dalam merubah cara seseorang untuk belajar, untuk memperoleh informasi, menyesuaikan informasi dan sebagainya[3].

Media pembelajaran merupakan suatu alat atau perantara yang berguna untuk memudahkan proses belajar mengajar, dalam rangka mengefektifkan komunikasi antara guru dan siswa. Hal ini sangat membantu guru dalam mengajar dan memudahkan siswa menerima dan memahami pelajaran. Proses ini membutuhkan guru yang mampu menyelaraskan antara media pembelajaran dan metode pembelajaran[4].

Pemakaian media pembelajaran dalam proses belajar mengajar juga dapat membangkitkan keinginan dan minat yang baru bagi siswa, membangkitkan motivasi belajar, dan bahkan membawa pengaruh psikologis terhadap siswa. Selain dapat meningkatkan motivasi belajar siswa, pemakaian atau pemanfaatan media juga dapat meningkatkan pemahaman siswa terhadap pelajaran.

Media yang dimanfaatkan memiliki posisi sebagai alat bantu guru dalam mengajar. Misalnya grafik, film, slide, foto, serta pembelajaran dengan menggunakan komputer. Hal ini dimaksudkan untuk menangkap, memproses, dan menyusun kembali informasi visual dan verbal. Sebagai alat bantu dalam mengajar, media diharapkan dapat memberikan pengalaman kongkrit, motivasi belajar, mempertinggi daya serap dan tingkat belajar siswa[5].

\section{METODE KEGIATAN PENGABDIAN}

Kegiatan ini terdiri atas tiga kegiatan utama, yakni pertama penyampaian konsep atau teori tentang dasar-dasar multimedia, jenis-jenis multimedia, pemanfaatan multimedia, dan pembuatan presentasi menggunakan PowerPoint yang efektif dan interaktif. Kedua, pelatihan pembuatan bahan ajar menggunakan perangkat lunak PowerPoint. Ketiga, evaluasi kemampuan peserta pelatihan dalam pembuatan bahan ajar berbasis multimedia.

Pada tahap pertama, peserta pelatihan diberi dasar-dasar yang berkaitan dengan multimedia dan penggunaannya. Pada tahap ini para peserta dirangsang untuk lebih tertarik menggunakan media-media terkini karena secara umum lebih efektif daripada cara konvensional.

Pada tahap kedua, secara khusus peserta diberi wawasan mengenai perangkat lunak PowerPoint. Pada tahap ini peserta ikut mempraktekkan apa yang disampaikan oleh pemateri. Pertanyaan dan keingintahuan kerap muncul dalam sesi ini.

Tahap selanjutnya adalah tahap evaluasi. Pada tahap ini peserta pelatihan diminta untuk membuat sebuah presentasi menggunakan perangkat lunak PowerPoint baik secara individu maupun kelompok. Slide presentasi tersebut kemudian dipresentasikan di depan kelas dan dinilai kelemahan dan kelebihannya oleh pemateri. Hasil dari evaluasi tersebut sangat bermanfaat untuk pembuatan slide-slide berikutnya.

Dalam menjawab permasalahan-permasalahan yang dihadapi para pengajar di Yayasan Ali Imron terkait penggunaan multimedia dalam penyusunan bahan ajar, hasil analisis dapat diuraikan sebagai berikut: melalui analisis situasi dapat diambil kesimpulan bahwa sebagai besar pengajar masih mengalami kesulitan dalam pengoperasian komputer, terlebih untuk perangkat lunak PowerPoint. Keterampilan yang diberikan melalui pelatihan penyusunan bahan ajar berbasis multimedia ini secara teori dan praktek membuat peserta pelatihan mampu untuk melakukan perubahan cara presentasi dan penyampaian materi pelajaran menjadi lebih efektif dan interaktif.

\section{A. Tahap Persiapan}

Dalam pelaksanaannya, program ini dibagi menjadi tiga tahapan, yakni sebagai berikut:

Tahap persiapan mencakup beberapa hal sebagai berikut:

1. Observasi Lapangan

Observasi dilakukan pada awal pelaksanaan program. Observasi tersebut dimaksudkan untuk mempelajari dan memahami kondisi Yayasan Ali Imron baik dari segi ketersediaan fasilitas pendukung pembelajaran berbasis multimedia, dukungan sekolah akan terciptanya pembelajaran berbasis multimedia, maupun kemampuan pengajar dalam mengorepasikan komputer dan menyusun presentasi dengan beberapa program standar seperti Microsoft PowerPoint.

Pemilihan Madrasah Yayasan Ali Imron sebagai lokasi pelaksanaan program didasarkan pada pertimbangan antara lain:

a. Yayasan Ali Imron merupakan sekolah yang memiliki fasilitas multimedia yang memadai dan relatif lengkap.

b. Dukungan terhadap pengembangan penyusunan bahan ajar berbasis multimedia sangat tinggi.

c. Meski memiliki fasilitas multimedia yang cukup lengkap, akan tetapi sebagian besar pendidiknya belum cukup familiar dengan program presentasi seperti PowerPoint dengan fitur-fitur tingkat lanjutnya. 
d. Keingintahuan dan semangat peserta pelatihan sangat tinggi dalam peningkatan kemampuan menyusun bahan ajar berbasis multimedia.

e. Yayasan berkeinginan kuat untuk mengembangkan mutu pengajaran melalui perbaikan kualitas penyampaian bahan ajar.

2. Mengajukan Perizinan Program Pengabdian Masyarakat di Yayasan Ali Imron.

\section{B. Tahap Pelaksanaan Program}

Program ini dilaksanakan di Yayasan Ali Imron dalam bentuk pelatihan, yaitu:

1. Penyampaian konsep dasar, jenis, dan pemanfaatan multimedia, serta pengantar penyusunan presentasi menggunakan PowerPoint yang efektif dan interaktif.

2. Pelatihan pembuatan bahan ajar menggunakan perangkat lunak PowerPoint.

3. Evaluasi kemampuan peserta pelatihan dalam pembuatan bahan ajar berbasis multimedia.

\section{Tahap Evaluasi Program}

Tahap evaluasi dilaksanakan untuk mengetahui efektifitas dan keberhasilan pelaksanaan program. Evaluasi dilaksanakan pada tahap akhir program pelatihan. Pada tahap ini para peserta pelatihan diminta untuk membuat slide presentasi dengan menggunakan software PowerPoint. Slide presentasi tersebut kemudian dipresentasikan di depan para pelatih dan peserta pelatihan yang untuk selanjutnya dievaluasi kekurangan dan kelebihannya. Sehingga dari sesi ini peserta pelatihan dapat memberi inspirasi kepada peserta yang lain dalam penyusunan slide presentasi masing-masing.

\section{HASIL DAN PEMBAHASAN}

Tahap pertama dalam pelatihan ini adalah penyampaian konsep dasar multimedia. Sesi awal ini dikhususkan untuk membuka paradigma baru bagi para peserta pelatihan mengenai multimedia dan jenisjenis multimedia yang bisa digunakan dalam proses belajar mengajar. Multimedia tidak dipandang sebatas alat-alat modern yang mahal dan langka dimana penggunaannya membutuhkan keahlian khusus yang tidak dapat dipelajari dalam waktu singkat.

Cakupan dan pentingnya penggunaan multimedia menjadi kunci pokok pembahasan dalam sesi pertama ini. Diberikan pula perbandingan antara mengajar dengan cara konvensional dengan pengajaran yang melibatkan perangkat multimedia. Rasa penasaran dan keingintahuan peserta pelatihan meningkat seiring pemaparan keragaman dan keefektifan multimedia dalam menjelaskan banyak hal yang tidak bisa dilakukan dengan cara konvensional. Hal ini dibuktikan dengan banyaknya pertanyaan yang diajukan seputar penyusunan presentasi berbasis multimedia.

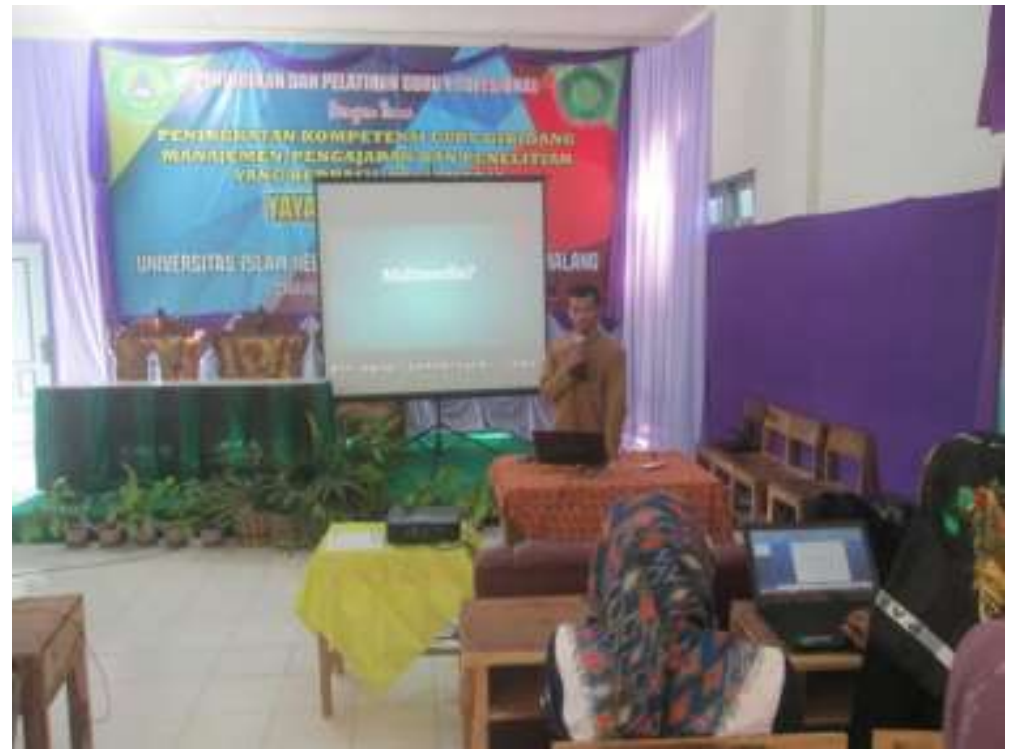

Gambar 1. Pemaparan sejarah, jenis dan pentingnya multimedia.

Pada tahap pertama ini peserta pelatihan diajak untuk membuka wawasan dan pemikiran baru guna meningkatkan mutu pembelajaran. Peningkatan tersebut dilakukan melalui presentasi-presentasi berkualitas yang membantu pelajar memahami materi pelajaran secara lebih efektif dan lebih mudah. 
Sedangkan tahap kedua program pelatihan ini adalah pembuatan slide dengan menggunakan program PowerPoint. Pembuatan slide tidak semata-mata dilakukan oleh pemateri dimana peserta pelatihan hanya diam mengamati. Akan tetapi pada sesi ini peserta pelatihan diminta untuk membuat suatu presentasi dengan PowerPoint di laptop masing-masing.

Peserta dan pemateri terlibat aktif dalam penyusunan dan penyempurnaan slide yang dibuat oleh peserta. Pemateri dibantu oleh beberapa rekan mengamati satu persatu hasil desain presentasi oleh peserta. Dalam sesi ini tidak jarang muncul beberapa ide kreatif dari peserta. Ide-ide tersebut berangkat dari masalah yang sering dihadapi saat proses kegiatan belajar mengajar di kelas berlangsung. Beberapa kendala dan masalah yang ditemui dalam pengajaran tanpa menggunakan PowerPoint banyak didiskusikan untuk dipecahkan.

Pembuatan slide presentasi dimulai dari yang paling sederhana, diantaranya: 1). Penyisipan gambar, audio, dan video; 2). Konversi list menjadi SmartArt; 3). Teknik layering dalam memunculkan tiap baris konten slide secara bertahap; 4). Beberapa animasi teks dan transisi slide dasar; serta 5). Navigasi antar slide menggunakan mouse maupun shortcut.

Pada tahap ini juga dikenalkan kemampuan tak biasa yang dimiliki oleh program Microsoft PowerPoint. Beberapa fitur tersebut contohnya adalah plugins dari program-program lain seperti embedding liveweb, Geogebra, Wolfram Mathematica, dan lain sebagainya. Dengan plugins tersebut PowerPoint lebih ampuh untuk digunakan dalam menjelaskan fenomena-fenomena yang terjadi dari aplikasi materi pelajaran yang didalami. Fenomena tersebut misalnya dalam pelajaran fisika gerak jatuh bebas, gaya gesekan benda dengan pemberat dan katrol tetap, serta simulasi kecepatan dan percepatan. Sedangkan contoh dalam pelajaran matematika misalnya simulasi kurva fungsi linier dan nonlinier, gerak harmonik, transformasi bangun, dan lain sebagainya

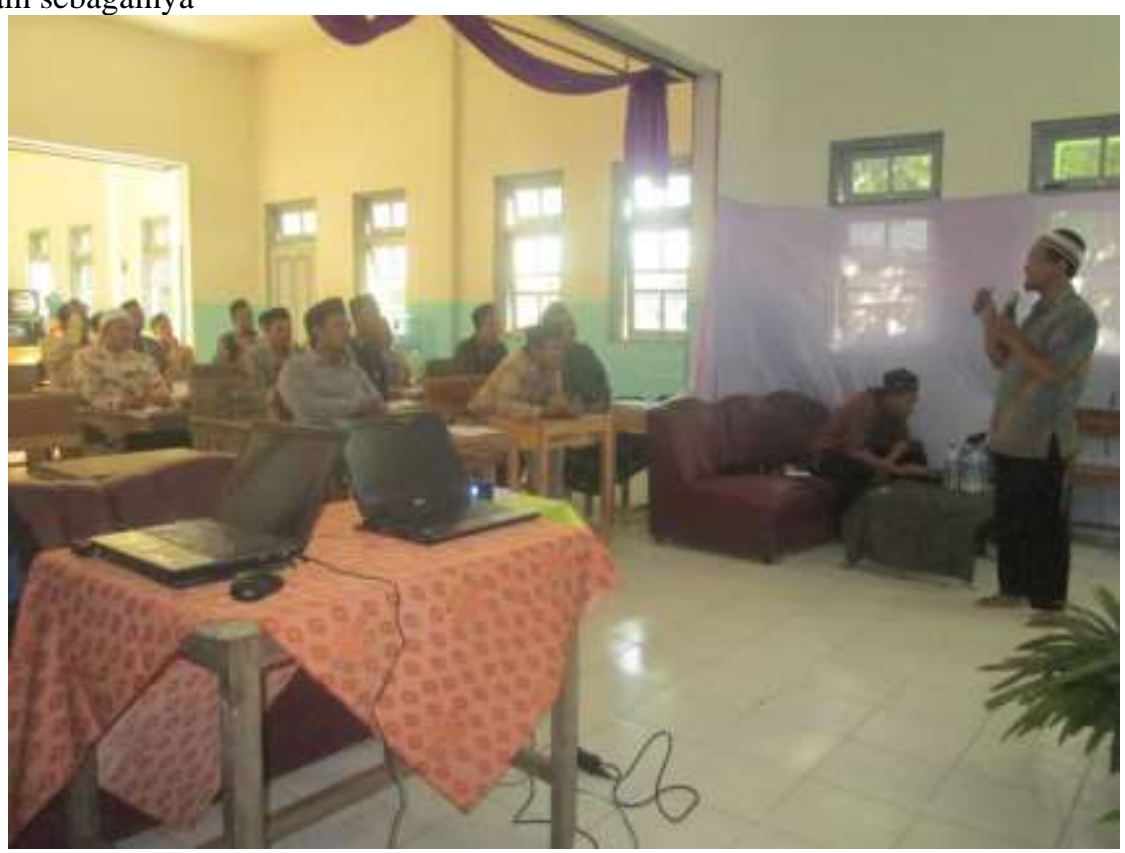

Gambar 2. Teknik penyusunan presentasi yang menarik dan efektif. 


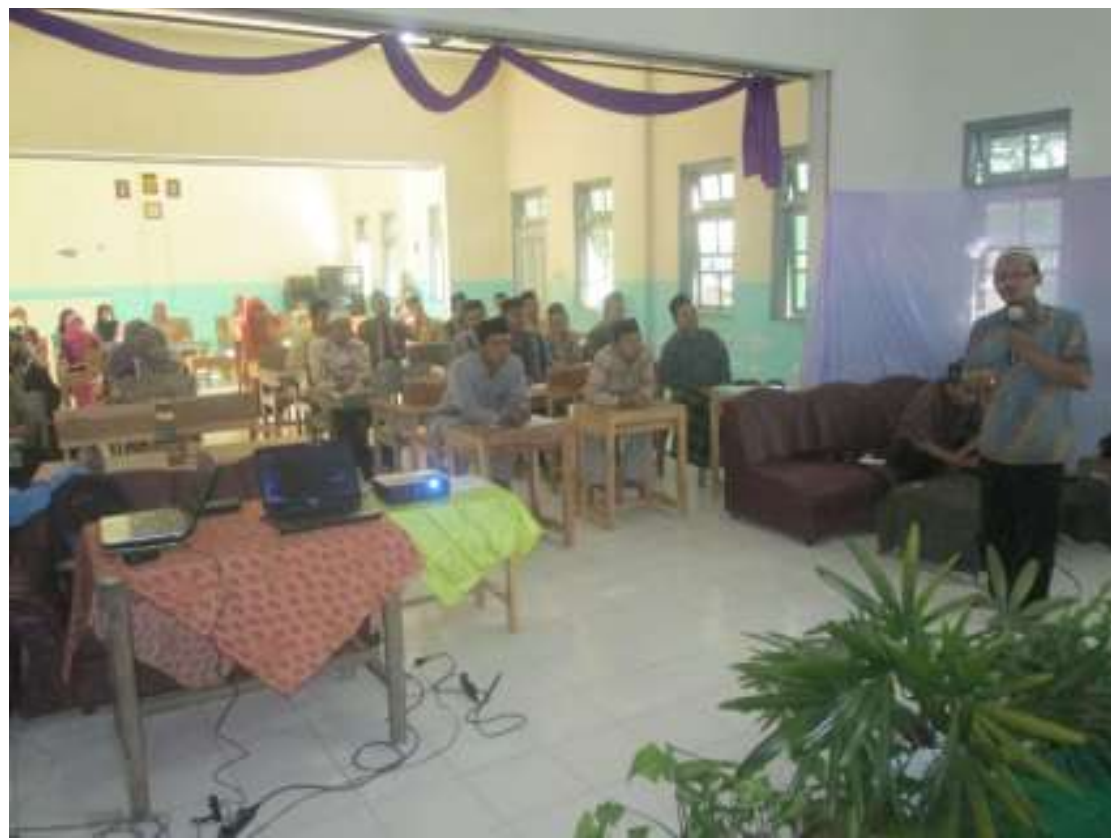

Gambar 3. Menguak kemampuan luar biasa PowerPoint melalui plugins dari program lain.

Tahap terakhir program pelatihan ini adalah evaluasi. Evaluasi dilakukan pada pertemuan ke dua pada hari yang berbeda. Pada pertemuan kedua ini para peserta pelatihan menunjukkan slide presentasi hasil karyanya yang merupakan PR dari pertemuan sebelumnya. Beberapa dari slide presentasi tersebut dipresentasikan di depan kelas. Karena keterbatasan waktu, slide presentasi peserta lain tidak dipresentasikan di depan kelas. Presentasi tersebut diperiksa oleh pemateri dan tim di laptop masing-masing peserta latihan.

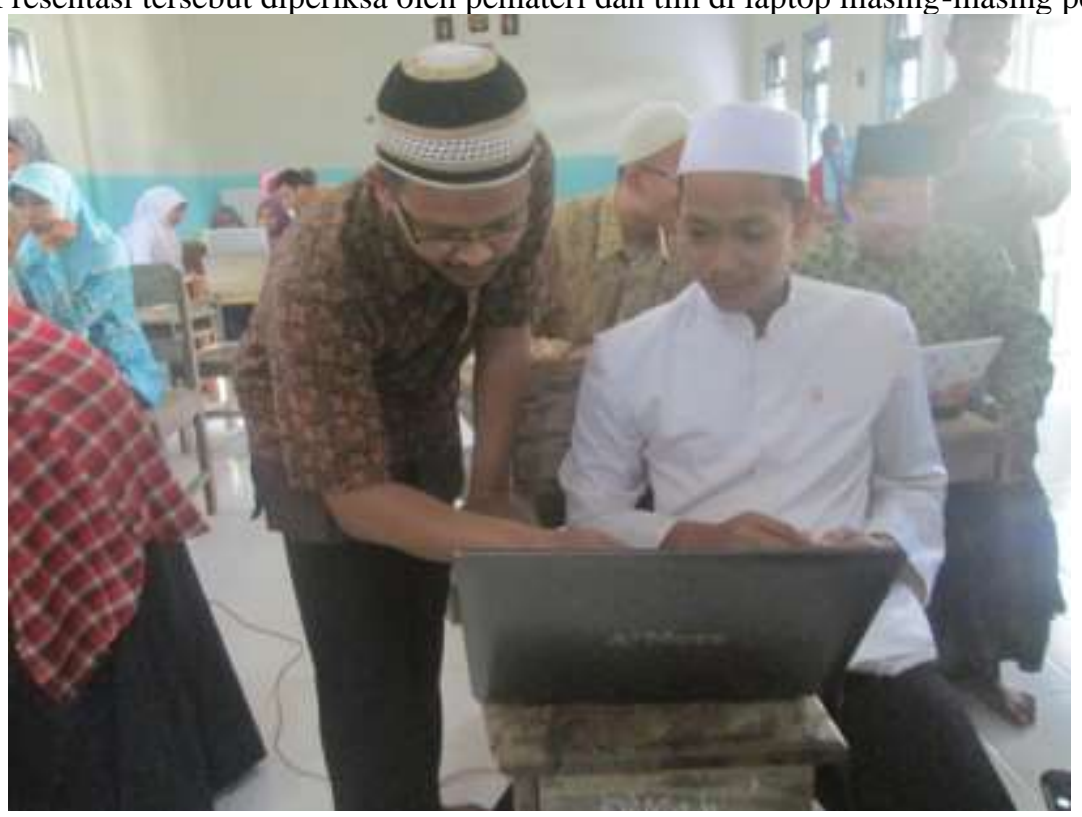

Gambar 4. Pendampingan peserta dalam penyusunan bahan ajar berbasis multimedia.

Dari sesi evaluasi ini diperoleh banyak masukan, gagasan, dan ide baru terkait keefektifan presentasi yang disusun menggunakan program PowerPoint. Banyak dari pengajar yang tidak terlalu sering menggunakan presentasi menggunakan PowerPoint menanyakan beberapa hal yang PowerPoint bisa lakukan untuk mendukung proses pengajaran. Beberapa dari mereka pernah mendengar suatu istilah dalam presentasi tapi tidak mengetahui bahwa PowerPoint bisa melakukannya. Dari pembahasan yang sederhana berkembang pembahasan yang cakupannya lebih luas dan merupakan materi tingkat lanjut dalam penyusunan presentasi. Hal tersebut merupakan hal yang bagus karena berangkat dari rasa penasaran, kegiatan pengembangan penyusunan presentasi berbasis multimedia akan berkembang dan menjadi lebih bermanfaat. 
Dapat disimpulkan bahwa secara umum peserta pelatihan memahami konsep dan materi yang disampaikan pada pertemuan sebelumnya (pelatihan tahap pertama dan kedua), sehingga mampu menerapkan pengetahuan tersebut dalam slide presentasi yang dibuat oleh masing-masing peserta. Dari sama sekali tidak tahu menjadi sedikit tahu dan kemudian tahu merupakan hal yang tidak mudah. Akan tetapi para pengajar di Yayasan Ali Imron menunjukkan bahwa mereka mampu melakukannya dengan sangat baik.

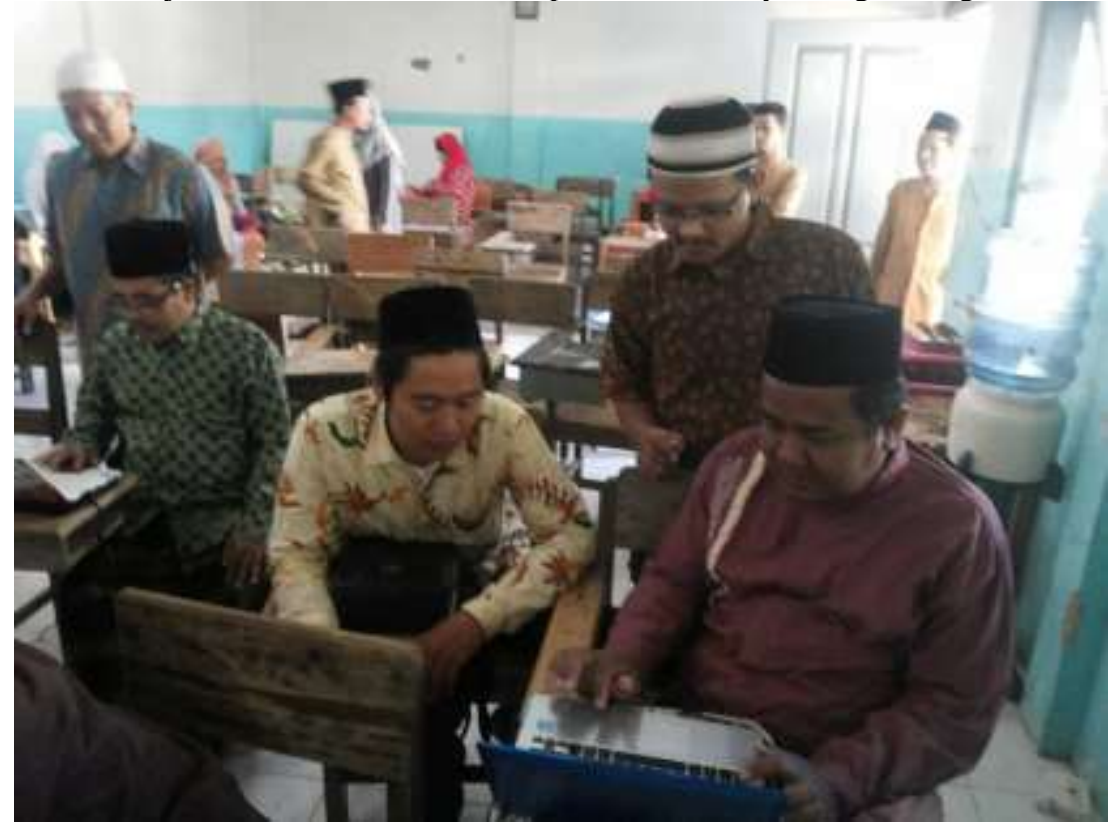

Gambar 5. Pemateri memeriksa slide PowerPoint hasil karya peserta.

Hasil presentasi untuk selanjutnya dikumpulkan sebagai arsip dan beberapa diantara presentasi yang bagus diperbaiki kembali dan dijadikan template untuk digunakan dalam presentasi riil saat kegiatan belajar mengajar.

\section{A. Pembahasan}

a) Kegiatan pengabdian kepada masyarakat yang dilaksanakan di Yayasan Ali Imron secara umum dilakukan dalam tiga tahap, yaitu: 1). Penyampaian dasar multimedia dan pentingnya multimedia dalam pembelajaran; 2). Penyusunan presentasi yang efektif dan efisien menggunakan program PowerPoint; dan 3). Evaluasi hasil materi yang disampaikan pada pertemuan sebelumnya.

b) Penyajian pelatihan pentingnya menyusun bahan ajar berbasis multimedia dilaksanakan dengan metode ceramah dan praktek. Kunci dari berkembangnya materi pelatihan ini terletak pada tanya jawab baik formal maupun informal yang diadakan pada setiap sesi. Dari pertanyaan-pertanyaan yang dilontarkan peserta diperoleh banyak masukan terkait penyusunan slide presentasi yang efektif dan menarik.

c) Ditemui kemampuan peserta yang sangat beragam. Ada yang sudah mahir dan sering menggunakan aplikasi PowerPoint, tapi ada juga yang baru belajar tahap dasar. Perbedaan pemahaman tersebut tidak menghambat proses pelatihan, justru dari situ para peserta pelatihan mampu untuk saling bertukar fikiran, sehingga membuat peserta lebih aktif, tidak hanya mendengarkan ceramah dan mempraktekkan apa saja yang pemateri sampaikan.

\section{B. Faktor Pendukung dan Penghambat Kegiatan.}

Kegiatan pengabdian masyarakat ini menunjukkan keberhasilan apabila dalam prosesnya terjadi perubahan-perubahan pada penyusunan presentasi di Yayasan Ali Imron ke arah yang lebih baik. Adapun beberapa indikator pencapaian kegiatan pengabdian pada masyarakat ini adalah sebagai berikut:

a. Kehadiran peserta dalam pembelajaran mencapai $100 \%$.

b. Partisipasi aktif sebagian besar peserta dengan mengajukan pertanyaan substantif dan teknis dalam proses pelatihan.

c. Keterlibatan seluruh peserta dalam kegiatan penyusunan presentasi berbasis multimedia.

d. Keterlibatan dalam kegiatan demonstrasi hasil karya masing-masing peserta pelatihan dalam sesi evaluasi.

e. Kehadiran seluruh peserta dalam kegiatan evaluasi atas hasil pelatihan pada hari berikutnya. 
Beberapa uraian di bawah ini menunjukkan beberapa faktor pendukung dan penghambat yang ditemui dalam pelaksanaan pengabdian pada masyarakat di Yayasan Ali Imron Pakamban Sumenep.

Berikut ini beberapa faktor pendukung yang di temui selama pelaksanaan pelatihan di Yayasan Ali Imron Pakamban Sumenep. Diantaranya adalah:

1. Letak Yayasan Ali Imron Pakamban Sumenep sebagai faktor pendukung, karena sangat mudah dijangkau. Tidak ditemui kendala yang berarti terkait perjalanan menuju ke lokasi pelatihan.

2. Frekuensi pertemuan dengan peserta pelatihan yang cukup. Adanya dukungan dari sekolah untuk dilaksanakannya pelatihan lebih dari satu kali. Pihak sekolah akan lebih senang jika pelatihan ini dilakukan secara kontinu dan tidak hanya satu periode ini saja.

3. Tersedianya sarana dan prasarana yang mendukung diadakannya latihan. Yayasan Ali Imron Pakamban Sumenep mempunyai fasilitas multimedia yang cukup lengkap. Hal ini sangat mendukung proses pelatihan.

4. Para peserta membawa laptop masing-masing dalam pelatihan. Dengan demikian pelatihan yang dilakukan menjadi lebih efektif. Karena saat pemateri memberikan materi terkait presentasi, para peserta dapat langsung mencobanya di laptop masing-masing.

5. Semangat peserta pelatihan yang sangat tinggi. Hal ini bisa dilihat dari tingkat kehadiran peserta dari tahap pertama hingga tahap terakhir. Terlebih lagi banyak dari peserta pelatihan yang ingin meneruskan pelatihan dan berharap pelatihan ini tidak hanya berhenti di satu gelombang saja.

6. Dukungan sekolah terkait pelatihan ini sangat tinggi. Yayasan Ali Imron memiliki keinginan untuk lebih mengefektifkan kembali cara pengajaran yang dilakukan di sekolah tersebut. Pelatihan ini dinilai sekolah sangat bermanfaat dan pihak sekolah setuju untuk meneruskan pelatihan ini hingga beberapa gelombang. Bahkan berkeinginan untuk dijadikannya pelatihan ini kontinu dalam jangka waktu yang lama.

7. Tahap evaluasi diikuti oleh semua peserta pelatihan. Adanya partisipasi aktif peserta pelatihan dalam tahap evaluasi menunjukkan semangat dan keinginan peserta untuk menggali lebih dalam tentang cara penyusunan presentasi yang baik dan efektif.

Selain terdapat faktor pendukung di atas, ditemui juga beberapa faktor penghambat dalam pelaksanaan kegiatan pengabdian pada masyarakat ini, diantaranya:

1. Tidak meratanya pengetahuan tentang presentasi sebelum diadakannya pelatihan ini. Hal ini mengakibatkan beberapa materi harus diulang-ulang. Sehingga ada yang masih bingung, ada pula yang sudah sangat mahir.

2. Masih ditemui sedikit ketidaktelatenan dari beberapa peserta pelatihan. Hal ini terjadi terutama saat materi yang disampaikan terasa sangat sulit. Banyak tool dan menu yang dilibatkan dalam satu materi membuat beberapa peserta pelatihan yang kurang familiar dengan program menjadi bingung dan cepat lupa.

3. Ada beberapa guru sebagai peserta pelatihan ini yang dalam kesehariannya masih menggunakan cara konvensional dalam mengajar. Ada pula beberapa dari mereka yang tidak langsung merubah cara presentasi setelah pelatihan ini. Hal ini dapat mengakibatkan ilmu yang telah didapatkan menjadi sedikit demi sedikit terlupakan.

4. Beberapa dari peserta pelatihan, terutama guru-guru yang sudah senior, tidak cukup familiar dengan komputer dan cara mengoperasikannya.

\section{KESIMPULAN}

Peningkatan kualitas presentasi sebagai bahan ajar berbasis multimedia di Yayasan Ali Imron memperoleh respon yang positif. Para guru-guru mengikuti pelatihan ini dengan penuh semangat dan antusias. Keinginan peserta untuk menggunakan presentasi multimedia bertambah drastis sesaat setelah materi pertama, yaitu tentang jenis multimedia yang dapat dipakai dalam pembelajaran dan manfaat penting menyusun presentasi berbasis multimedia. Keingintahuan para guru-guru Yayasan Ali Imron terpupuk saat pemaparan materi bagaimana menyusun presentasi yang efektif. Banyak pertanyaan-pertanyaan mendasar dan tingkat lanjut yang dilontarkan para peserta. Dari pertanyaan-pertanyaan tersebut didapatkan ide-ide baru pengembangan bahan ajar berbasis multimedia.

Kegiatan ini mendapat respon positif baik dari guru-guru selaku peserta kegiatan maupun dari pihak sekolah selaku penyelenggara acara. Tahap evaluasi diikuti oleh semua peserta pelatihan. Dalam tahap ini semua peserta membuat slide presentasi yang kemudian dipresentasikan di depan kelas. 


\section{UCAPAN TERIMAKASIH}

Sampaikan ucapan terimakasih anda kepada pihak-pihak terkait yang mendukung berlangsungnya penelitian dan pengabdian anda. Anda dapat menyebutkan instansi-instansi yang terkait dalam bab ini.

\section{DAFTAR PUSTAKA}

[1] M. B. Baihaqi, "Pendidikan dan Digitalisasi di Era Milenial," Sabtu, 23/12/17, 2017.

[2] T. Hakim, "Faktor - faktor yang mempengaruhi belajar," in Belajar Secara Efektif, 2000.

[3] Ahmad Esa, Baharom Mohamad, and Siti Nasrah Mukhtar, "Peranan Multimedia Di Dalam Pembelajaran Kanakkanak," Semin. Kebangs. JPPG 2007 Teknol. Dalam Pendidik., 2007.

[4] M. Maimunah, "METODE PENGGUNAAN MEDIA PEMBELAJARAN," Al-Afkar J. Keislam. Perad., 2016.

[5] J. J. Gultom, "Pemanfaatan Media Dalam Proses Belajar Mengajar," J. Pendidik., 2012. 